\title{
Creating Online Worlds: The Future Of Student Work
}

Rodney P. Riegle, (E-mail: rpriegle@ilstu.edu), Illinois State University

\begin{abstract}
Traditional schoolwork is out of step with twenty-first century life and work. In the future, student work will focus on creating interactive online worlds instead of on writing paper-print essays.
\end{abstract}

The future is here. It's just not widely distributed yet. William Gibson

\section{INTRODUCTION}

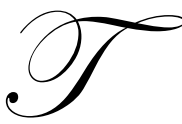

here has been a dramatic negative shift in the attitude of students toward the work they do in school. Only 28 percent of high schools seniors rated their schoolwork as meaningful in 2000, down from 40 percent in 1983. Only 21 percent reported that their courses were interesting in 2000, as compared to 35 percent in 1983. Even among A-students, fewer and fewer believe that their schoolwork will be important later in life. $^{1}$

This degeneration of student attitude toward schoolwork is yet another sign of the lag between school practices and social change. In the twentieth century, student work was dominated by paper-print assignments, particularly essays. This was a reflection of the dominant media technology of that century - books, magazines, newspapers, radio, and television. But those days are gone. The number of adult Americans who read newspapers, for example, dropped from 78 percent to 54 percent between 1970 and $2001 .^{2}$

In the twenty-first century, the dominant media technology of today's students is the Internet. In fact, Internet use among 18 year olds and younger is approaching 100 percent $^{3}$ while 18 - to 34 -year-olds are far more apt to $\log$ on to the Internet (46 percent) than watch TV (35 percent), read a book ( 7 percent), turn on a radio ( 3 percent), read a newspaper (also 3 percent) or flip through a magazine (less than 1 percent). ${ }^{4}$

\section{ONLINE WORLDS}

Today's students not only prefer a different media technology, they also have different entertainment preferences. Video games ( $\$ 12$ billion annually) have now passed movies ( $\$ 8$ billion annually) as the most popular form of entertainment in the U.S. ${ }^{5}$ Seventy percent of U.S. college students play video games (thirty-two percent even admit to playing video games during class without the knowledge of their instructors). ${ }^{6}$

In addition to being one of the most popular video game genres (along with adventure and sports), RPGs are perhaps the most appropriate video game genre for educational purposes. RPG stands for Role-Playing Game. A roleplaying game is a game in which each player takes the part of a character and participates in an adventure. Dungeons and Dragons ${ }^{7}$ is one example of a popular role-playing game (originally played in-person with dice) that is set in a medieval fantasy world. Oregon Trail, ${ }^{8}$ where students take the role of nineteenth century pioneers in the American west, is one early example of an educational RPG (originally played via a CD on a computer).

There are currently more than 25 million people worldwide playing RPGs online. ${ }^{9}$ Below are some of the most popular MMORPGs (Massively Multiplayer Online Role-Playing Games): ${ }^{10}$ 


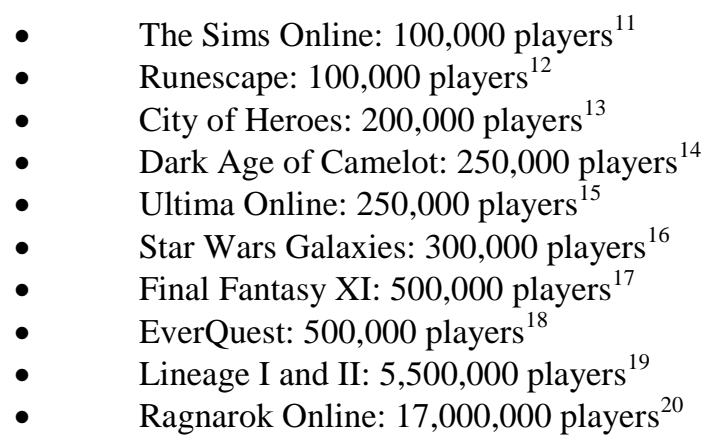

Since each of these online games requires a monthly subscription fee (usually \$10-15 per month) to play, there is clearly something fundamentally attractive about online worlds. Leveraging this attraction for educational purposes seems like a no-brainer. Thus, instead of students writing yet another boring, derivative paper-print essay about, for example, civil rights, they could be asked to create an online civil rights RPG where visitors can play the role of any number of characters in real or imagined worlds with real or imagined civil rights issues and events.

\section{BARRIERS TO THE FUTURE}

There are at least four potential barriers to the transformation of student work from paper-print essays to educational RPG websites - skills, costs, theory, and assessment.

- Creating educational RPG websites requires some instructional design skills and some understanding of the characteristics of good RPGs. Fortunately, because of their vast game-playing experience today's students intuitively understand the latter while today's teachers are trained in the former. Each group simply needs to share their respective expertise. As for the technical skills, it is no more difficult to use an html editor (such as Microsoft FrontPage ${ }^{21}$ ) than it is to use a word processor.

- The costs of paper have skyrocketed while the costs of electronic media have plummeted. For example, textbook prices have been doubling every ten years since 1965. The average cost of a single textbook now exceeds $\$ 100 .^{22}$ In contrast, there are now many places on the Internet that will store student web pages for free. ${ }^{23}$ The point is that it is already cheaper for students to create websites than it is for them to create paper materials.

- Constructivism, collaborative learning, project-based learning, problem-based learning, independent learning, engaged learning, self-directed learning, and situative learning have all been recently touted as the latest and greatest approaches to student work. They share a focus on active student involvement, highly relevant learning, and skills transferable to real life problem-solving. These are exactly the kinds of characteristics that student-designed game-based websites feature. Thus, the theoretical basis for the transformation of student work already exists, although it might be prudent for educational theorists to examine the literature on RPG theory. ${ }^{24}$

- $\quad$ Traditional assessment judges students by essays and factual memorization (often without a relevant context) even though that knowledge is easily accessible online. That model of assessment is no longer valid. Today, actions and events are interconnected, and there should be a premium on getting students to think reflectively about complex systems. Designing educational video games is one of the best ways to do that. For example, in games like Civilization ${ }^{25}$ or Rise of Nations ${ }^{26}$ (both of which are best-selling computer-based video games), the player manages a civilization's people, politics, and resources in settings that can range from ancient times to a sci-fi future. Designing such worlds requires a deep understanding of systems and how they are interconnected. Student learning is maximized when the game designers are so caught up in the creation of their worlds that they don't realize they are learning or how much they are learning. But how should the students who produce such games be assessed? First, well-designed video games must immerse players in intricately detailed worlds and make them rely on problem-solving skills to reach defined goals. Second, players must learn new skills and see the consequences of their knowledge, or their lack of knowledge, during play. Third, successful players must exhibit reflective thinking about complex systems 
(e.g., workplaces, communities, government, global institutions, the environment, etc.). Designing a good video game requires that the designers learn facts, but the real value of game design is getting designers to think deeply about complex systems. Designing a game like Civilization, for example, can get the designer to see that history could have happened in different ways and that things happen for many different reasons which interact in complex ways. These are the intellectual skills and dispositions that a modern assessment model must focus on.

In summary, the barriers to the transformation of student work, although not insignificant, seem far from insurmountable.

\section{CONCLUSION}

Student-designed RPG websites motivate students to produce high quality work in ways that paper-print essays cannot. The fact that websites are globally and publicly accessible allows friends and relatives (as well as total strangers) to review student work. In addition, websites can provide a link between school and work (e.g., electronic portfolios can help students get a job). Finally, and perhaps most importantly, a sense of ownership results when a student creates his or her own RPG world and shares it with the rest of the world. For example, students in my online RPG course (EAF 228 ${ }^{27}$ ) create their own educational online RPGs. It is not uncommon for these students to continue working on their websites long after my course is over.

Requiring students to design online educational video games lends itself to nearly all academic disciplines. For example, geography is necessary for in-game navigation, art for landscape and architecture, political science for government and communities; history is essential for back-stories and for accurate re-creations of events, characters and societies; English for story and character development; music for sound and sound effects; philosophy for game values and cosmology; and so on. Indeed, the multi-disciplinary nature of video game design results in much deeper learning than traditional student work.

Although there is always a time lag between social change and educational change, social change eventually and inevitably begets educational change. Once it becomes common for students to create online worlds instead of write paper-print essays, student attitudes toward schoolwork will improve. This will persist until, of course, the next major shift in media technology (perhaps the holodeck ${ }^{28}$ ?), when the cycle will begin again.

\section{NOTES}

${ }^{1}$ Johnston, L. D., O'Malley, P. M., Bachman, J. G., \& Schulenberg, J. E. Monitoring the Future national survey results on drug use, 1975-2003. Volume I: Secondary school students (NIH Publication No. 04-5507). Bethesda, MD:

National Institute on Drug Abuse, 2004. 1 September 2005

<http://monitoringthefuture.org/pubs/monographs/vol1_2003.pdf >.

${ }^{2}$ Facts About Newspapers 2002. Newspaper Association of America. 1 September 2005

<http://www.naa.org/info/facts02/4 facts2002.html $>$.

3 The Digital Future Report: Surveying the Future: Year Four. USC Annenberg School Center for the Digital Future September 2004. 1 September 2005 <http://www.digitalcenter.org/downloads/DigitalFutureReport-Year4-2004.pdf>. ${ }^{4}$ Online Publishers Association. Generational Media Study. 21 September 2004. 1 September 2005

<http://www.online-publishers.org/pdf/opa_generational_study_sep04.pdf $>$.

${ }^{5}$ Entertainment Software Association. The Essential Facts About the Computer and Video Game Industry. 12 May 2004. 1 September 2005 <http://www.theesa.com/files/EFBrochure.pdf $>$.

${ }^{6}$ Jones, Steve. Let the games begin: Gaming technology and entertainment among college students. Pew Internet \& American Life Project, 6 July 2003. 1 September 2005 <http://www.pewinternet.org/reports/toc.asp?Report=93> .

${ }^{7}$ Dungeons \& Dragons Roleplaying Game Official Home Page. 1 September 2005 < http://www.wizards.com/dnd/>

${ }^{8}$ The Oregon Trail $5^{\text {th }}$ Edition. Broderbund. 1 September 2005

<http://www.broderbund.com/jump.jsp?itemID=147\&mainPID=147\&itemType=PRODUCT\&path=1\%2C2\%2C8\%2 C67\&iProductID $=147>$. 
${ }^{9}$ Woodcock, Bruce. An Analysis of MMOG Subscription Rates. 1 September 2005

$<$ http://pw1.netcom.com/ sirbruce/Subscriptions.html >.

${ }^{10}$ For more information on MMORPGs, see MMORPG. Wikipedia. 1 September 2005 $\langle$ http://en.wikipedia.org/wiki/MMORPG $>$.

${ }^{11}$ The Sims Online. Electronic Arts. 1 September 2005

$\langle$ http://www.eagames.com/official/thesims/thesimsonline/us/nai/index.jsp $>$.

${ }^{12}$ Runescape. Jagex Ltd. 1 September $2005<$ http://www.runescape.com/ $>$.

${ }^{13}$ City of Heroes. NCsoft. 1 September $2005<$ http://www.cityofheroes.com/ $>$.

${ }_{15}^{14}$ Dark Age of Camelot. Mythic Entertainment. 1 September $2005<$ http://www.darkageofcamelot.com/>.

${ }^{15}$ Ultima Online. Electronic Arts. 1 September $2005<$ http://www.uo.com/ $>$.

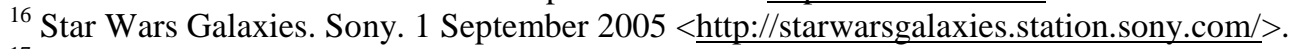

${ }^{17}$ Final Fantasy XI. Square Enix. 1 September $2005<$ http://www.playonline.com/ff11us/index.shtml $>$.

${ }^{18}$ EverQuest. Sony. 1 September $2005<$ http://eqlive.station.sony.com/>.

${ }^{19}$ Lineage. NCsoft. 1 September 2005 <http://www.ncsoft.net/eng/ncgames/lineage intro 01.asp $>$.

${ }^{20}$ Rognarok Online. Gravity Corp. 1 September $2005<$ http://www.ragnarokonline.com/ $>$.

${ }^{21}$ Microsoft Office Online: FrontPage 2003 Home Page. Microsoft. 1 September 2005

$<$ http://office.microsoft.com/en-us/FX010858021033.aspX >.

${ }^{22}$ Fairchild, Merriah. Ripoff 101: How the Current Practices of the Publishing Industry Drive up the Cost of College

Textbooks, CALPIRG. 29 January 2004. 1 September $2005<$ http://calpirg.org/reports/textbookripoff.pdf $>$.

${ }^{23}$ See, for example, Yahoo! Geocities. 1 September $2005<$ http://www.geocities.com/>.

${ }^{24}$ See, for example, Kim, John. RPG Theory. John Kim's Styles of Roleplaying Page. 1 September 2005

$<$ http://www.darkshire.net/ jhkim/rpg/theory/>.

${ }^{25}$ Civilization III: Home. 1 September $2005<$ http://www.civ3.com/>.

${ }^{26}$ Rise of Nations. Microsoft. 1 September $2005<$ http://www.microsoft.com/games/pc/riseofnations.aspx $>$.

${ }^{27}$ Riegle, Rodney. EAF 228: Social Foundations of Education. Illinois State University. 1 September 2005

$<$ http://www.coe.ilstu.edu/rpriegle/eaf228/>. This course was featured in the November 3, 2003 AACTE Briefs available online at http://www.aacte.org/Research/focus_tech_game.htm. The course title of EAF 228 is Social Foundations of Education. It was the world's first online course for teachers (1994) and the world's first online course-game (2000). The content of EAF 228 is history/philosophy/sociology of education (with a focus on information technology and the future). Its target is undergraduate teacher education majors (all grade levels and specialties) and it is offered every semester including summer. Enrollment is 100 students per semester (over 3,000 since 1994). EAF 228 is totally online (no meetings, no paper materials or texts) and asynchronous (independent of space and time). It utilizes collaborative learning (via a voluntary discussion board), mastery learning (student controlled pace and amount), multi-media (text, images, sound, music, video), video game design principles (story, quests, characters, map, voices, player's guide, etc.), automated online record keeping for the instructor (via ASP and an Access database), automated online feedback and progress reports for students (both individual and collective), standard HTML platform (designed and maintained by the instructor since 1994), no commercial products (such as WebCT or Blackboard). Visitors are encouraged to login and browse any or all parts of the course.

${ }^{28}$ A Holodeck is a "smart" virtual reality system as envisioned in the fictional Star Trek universe. It combines transporter, replicator, and holographic systems. The programs, projected via emitters within a specially outfitted but otherwise empty room, can create both "solid" props and characters as well as holographic backgrounds to evoke any vista, any scenario, and any personality - all based on whatever real or fictional parameters are programmed. While personal holoprograms relieve the stress and isolation of shipboard life for crew personnel, Holodecks are also used for tasks ranging from scientific simulations to tactical or even covert training. 